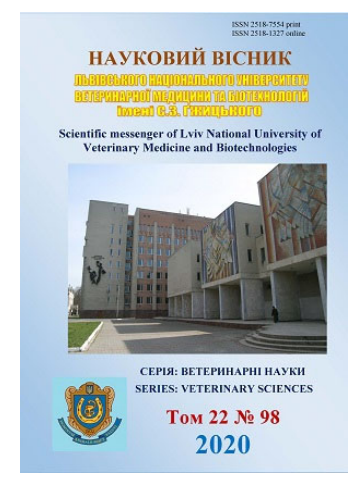

\author{
Науковий вісник Дьвівського національного університету \\ ветеринарної медицини та біотехнологій імені С.3. Гжицького. \\ Серія: Ветеринарні науки \\ Scientific Messenger of Lviv National University \\ of Veterinary Medicine and Biotechnologies. \\ Series: Veterinary sciences
}

UDC 619:615.357:621.1:636.2

\title{
The concentration of triiodothyronine and thyroxine in colostrum, milk and plasma of cows
}

\author{
A. V. Pan'kiv, M. R. Simonov
}

Stepan Gzhytskyi National University of Veterinary Medicine and Biotechnologies Lviv, Ukraine

Article info

Received 23.03.2020

Received in revised form 24.04.2020

Accepted 25.04.2020

Stepan Gzhytskyi National University of Veterinary Medicine and Biotechnologies Lviv, Pekarska Str., 50, Lviv, 79010, Ukraine. Tel.: +38-097-606-11-25 E-mail: pankivandriana@gmail.com
Pan'kiv, A. V., \& Simonov, M. R. (2020). The concentration of triiodothyronine and thyroxine in colostrum, milk and plasma of cows. Scientific Messenger of Lviv National University of Veterinary Medicine and Biotechnologies. Series: Veterinary sciences, 22(98), 69-73. doi: 10.32718/nvlvet9812

Milk contains key nutrients in optimal proportions, which makes it to be an important component of the human diet. Despite the fact that consumers receive with milk a significant amount of readily available nutrients, milk can be a source of dangerous factors of chemical and biological origin. The level of physiological hormones found in milk is not a limiting factor and is studied solely for scientific purposes. However, milk hormones can have a negative effect on the health of consumers. Based on this, the aim of this work was to study the concentration of triiodothyronine and thyroxine in colostrum, milk and blood plasma of cows at different stages of lactation. The secretion of the mammary gland and blood plasma of cows of Ukrainian black-and-white dairy breed, in their $2^{\text {nd }}-5^{\text {th }}$ lactations with milk yield 5100-5700 $\mathrm{kg}$ of milk per previous lactation was the object of the study. The concentration of triiodothyronine and thyroxine using enzyme-linked immunosorbent assay was investigated in withdrawn samples. The obtained data indicates that the highest level of secretion of iodine-containing thyroid hormones with milk is observed on $1^{\text {st }}$ $4^{\text {th }}$ days of lactation. Thereafter, the concentration of hormones in milk statistically significant decreases by 2.8-3-fold $(P<0.001)$ till 30-40 th day of lactation. The high concentration of iodine-containing hormones in colostrum allows to enhance metabolic processes in calves. Studies of the concentration of thyroid hormones in the blood plasma of cows showed a gradual increase from the beginning of lactation till $10^{\text {th }}$ $14^{\text {th }}$ and then till $30^{\text {th }}-40^{\text {th }}$ days of lactation. By $10^{\text {th }}-14^{\text {th }}$ days we observed 2.2-fold growth of triiodothyronine level $(P<0.001)$, and till $30^{\text {th }}-40^{\text {th }}$ days this parameter has increased by another $12.5 \%$. The level of thyroxine on $10^{\text {th }}-14^{\text {th }}$ days of lactation was higher, compared to such in the beginning of lactation by $62.2 \%(P<0.001)$, and by $30^{\text {th }}-40^{\text {th }}$ day increase was by $40.9 \%$. The main reasons for such changes are the formation of lactation dominant, the discharge of hormones secreted by the breast and the stimulation of metabolic processes during lactation. The prospects of further research lie in investigation of the dependence of triiodothyronine and thyroxine levels in the secretion of the mammary gland on productivity, breed, age and diet of animals.

Key words: food safety, hormones, thyroid gland, lactation.

\section{Концентрація трийодтироніну і тироксину в молозиві, молоці та плазмі крові корів}

\author{
А. В. Паньків, М. Р. Сімонов
}

Львівський національний університет ветеринарної медицини та біотехнологій імені С. 3. Гжиџького, м. Львів, Україна

Поживні речовини молока перебувають у оптимальних співвідношеннях, щзо робить його важливим компонентом раціону людини. Не дивлячись на те, щуо споживачі з молоком отримують значну кількість добової норми легкодоступних поживних речовин, молоко може бути джерелом небезпечних чинників хімічного та біологічного походження. Рівень фізіологічних гормонів, які знаходяться у молочі, не є лімітуючим фактором та досліджується виключно з науковою метою. Не зважаючи на це гормони молока 
можуть мати негативний вплив на здоров'я споживачів. Виходячи з иьього метою даної роботи було вивчити концентрацію трийодтироніну і тироксину в молозиві, молоці та плазмі крові корів на різних етапах лактаціі. Об 'єктом дослідження був секрет молочної залози та плазма крові корів чорно-рябої української молочної породи, 2-5 лактачї̈, продуктивністю 5100-5700 кг молока за попередню лактацію. У відібраних пробах досліджували концентрацію трийодтироніну та тироксину методом імуноферментного аналізу. Отриманий у ході виконання роботи ичифровий матеріал вказує на те, шчо найбільший рівень виділення з молоком йодовмісних гормонів щитоподібної залози реєструється на 1-4 добу лактацї. Далі концентрація гормонів у молоці вірогідно $(P<0,001)$ знижується у 2,8-3 рази до 30-40 доби лактації. Висока концентрація йодовмісних гормонів у молозиві дозволяє стимулювати обмінні процеси у телят. Дослідження концентрації гормонів щчитоподібної залози у плазмі крові корів показали поступове зростання від початку лактації до 10-14 і далі до 30-40 доби лактації. До 10-14 доби рівень трийодтироніну зріс у 2,2 рази (P<0,001), а до 30-40 доби ще на 12,5\%. Рівень тироксину на 10-14 добу лактації був вищим, порівняно із ї̈ початком, на 62,2\% (P<0,001), а на 30-40 - на 40,9\%. Основними причинами таких змін є формування лактаційної домінанти, виділення гормонів з секретом молочної залози та стимулювання обмінних процесів впродовж лактації. Перспектива подальших досліджень полягає у дослідженні залежності рівня трийодтироніну та тироксину в секреті молочної залози від продуктивності, породи, віку та годівлі тварин.

\section{Ключові слова: безпека продуктів харчування, гормони, щчитоподібна залоза, лактація.}

\section{Вступ}

В незбираному молоці корів знаходиться приблизно 972 унікальні сполуки, котрі утворюють 2,35 тисячі різних метаболічних структур (Foroutan et al., 2019). Крім протеїнів та ліпідів у молоці містяться молочний цукор, жиро- та водорозчинні вітаміни, мікро- і макроелементи, гормони й інші біологічно активні речовини. Хімічний склад молока є унікальним і залежить від багатьох факторів, зокрема породи, лінії, продуктивності, стадії лактації, клінічного стану тварини, годівлі, умов утримання та інших (Tsyupko, 2010). Але завжди поживні речовини молока перебувають у оптимальних співвідношеннях, що робить його важливим компонентом раціону людини.

Не дивлячись на те, що споживачі з молоком отримують значну кількість добової норми легкодоступних поживних речовин, молоко може бути джерелом небезпечних чинників хімічного та біологічного походження. Це, зокрема, антибіотики, пестициди, радіонукліди, залишки ветеринарних препаратів тощо. Вміст даних речовин контролюється відповідними лабораторіями і регламентується нормативними документами, що дозволяє забезпечити належний рівень безпечності та якості молока. Однак рівень фізіологічних гормонів, які знаходяться у молоці, не $\epsilon$ лімітуючим фактором та досліджується виключно 3 науковою метою. Гормони молока можуть мати негативний вплив на здоров'я споживачів. Зокрема занепокоєння викликає ряд публікацій (Rogers et al., 2006; Duarte-Salles et al., 2014; Frezza et al., 2018; Rieunier et al., 2019), котрі пов'язують виникнення онкологічних захворювань зі споживанням молока та молочних продуктів. Пояснюється це наявністю у молоці низки гормонів, зокрема інсуліноподібного фактору росту, пролактину, простагландинів, глюкокортикоїдів, естрогенів та інших гормонів (Malekinejad \& Rezabakhsh, 2015).

Виходячи $з$ цього метою даної роботи було вивчити концентрацію трийодтироніну і тироксину в молозиві, молоці та плазмі крові корів на різних етапах лактації.

\section{Матеріал і методи досліджень}

Матеріалом для досліджень були корови чорнорябої української молочної породи, 2-5 лактації, про- дуктивністю 5100-5700 кг молока за попередню лактацію. Відбір проб секрету молочної залози та плазми крові проведено протягом лютого - березня місяця. Молоко відбирали під час ранішнього доїння у стерильні ємності. Кров отримували з яремної вени у стерильні пробірки з гепарином. Далі молоко осаджували 0,1 н соляною кислотою з подальшим центрифугуванням (3 тис. об/хв протягом 15 хв) та видаленням жиру. Для отримання плазми кров відразу центрифугували при трьох тис. об./хв. Секрет молочної залози та крові відбирали на 1-3, 10-14 та 30-40 добу лактаціï. У отриманих пробах досліджували концентрацію трийодтироніну та тироксину методом імуноферментного аналізу із використанням тест-наборів фірми “DRG” (Німеччина).

Відбір проб проводили з урахуванням "Загальних етичних принципів експериментів на тваринах" (Україна, 2001) та згідно з положеннями “Європейської конвенції про захист хребетних тварин, які використовуються для експериментальних та інших цілей” (Страсбург, 1985).

Одержані дані опрацьовували в програмі Excel, визначаючи середню арифметичну величину (М), статистичну помилку середньої арифметичної величини (m), вірогідність різниці між середніми арифметичними двох варіаційних рядів $(\mathrm{P}<)$.

\section{Результати досліджень}

Проведені дослідження секрету молочної залози показали найвищий рівень трийодтироніну на 13 добу лактації (рис. 1). Протягом перших двох тижнів лактації концентрація гормону знизилася у $2,3$ рази (Р $<0,01)$, а до 30-40 доби - ще на $17,7 \%$. На 30-40 добу лактації загальне зниження рівня трийодтироніну в молоці склало 2,8 разу ( $\mathrm{P}<0,001)$, порівняно зі 1-3 добою.

Як видно 3 даних рис. 1, динаміка змін рівня тироксину була подібною. А саме, встановлено зниження концентрації до 10-14 доби удвічі $(\mathrm{P}<0,01)$ з подальшим зниженням ще на $33,6 \%(\mathrm{P}<0,05)$ до $30-$ 40 доби, коли рівень гормону був найнижчим за період дослідження. Загальне зниження концентрації гормону від початку лактації до 30-40 доби склало 3 рази $(\mathrm{P}<0,001)$. 


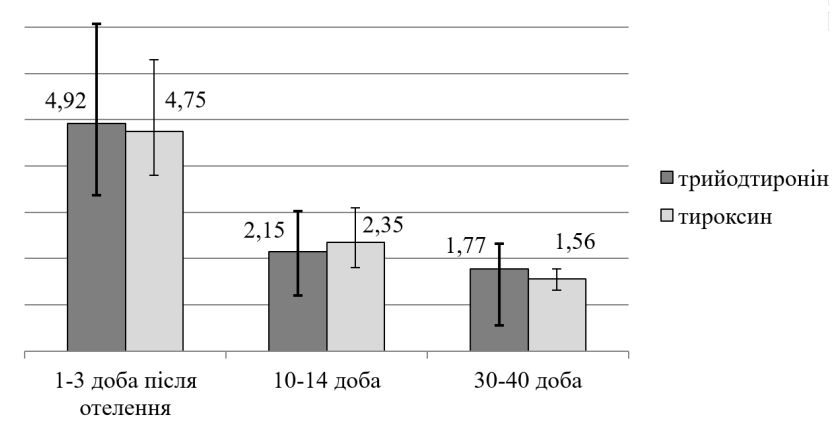

Рис. 1. Концентрація трийодтироніну та тироксину в секреті молочної залози корів, нмоль/л; $\mathrm{n}=10$

Слід відмітити, що протягом аналогічних періодів відбору проб секрету молочної залози рівень трийодтироніну та тироксину вірогідно не відрізнявся.

Проведені дослідження концентрації трийодтироніну в плазмі крові корів показали (рис. 2), що найнижчий рівень гормону був після отелення, а найвищий - на 30-40 добу лактації. До 10-14 доби рівень гормону зріс у 2,2 рази $(\mathrm{P}<0,001)$, а до 30-40 доби - ще на $12,5 \%$.

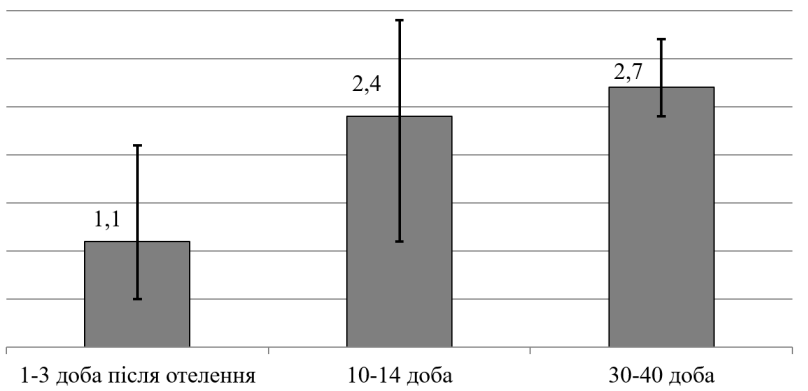

Рис. 2. Концентрація трийодтироніну у плазмі крові корів, нмоль/л; $\mathrm{n}=10$

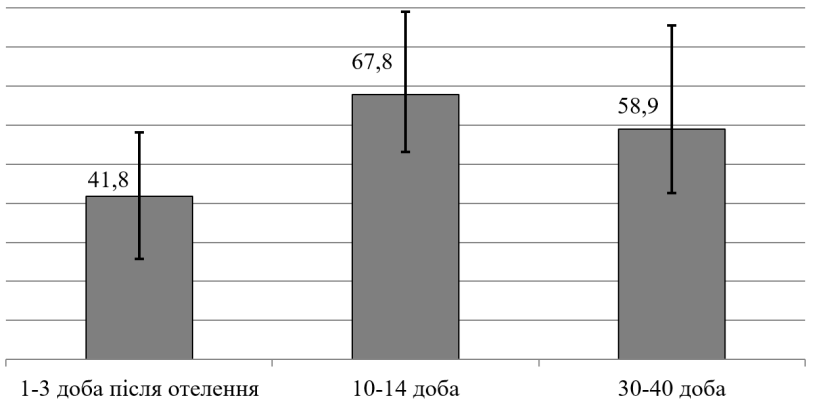

Рис. 3. Концентрація тироксину у плазмі крові корів, нмоль/л; $\mathrm{n}=10$

Як видно 3 даних рисунку 3 найвищий рівень тироксину встановлено у плазмі крові корів, котрі знаходилися на 10-14 добі лактації. Від початку лактації концентрація гормону зросла на 62,2% (P <0,001). На 30-40 добу лактації рівень тироксину був вищим, порівняно з іiї початком на 40,9 \% та водночас нижчим на 13,1 \%, порівняно 3 концентрацією, встановленою на 10-14 добу.

Протягом дослідного періоду найширші ліміти показника в межах однієї групи тварин встановлено за дослідження трийодтироніну в плазмі крові корів на 10-14 добу лактації, коли різниця між найменшим на найбільшим значенням відрізнялася утричі. Водночас найвужчі ліміти встановлено за дослідження трийодтироніну на 30-40 добу з коливаннями до $34 \%$.

\section{Обговорення}

Трийодтиронін - високоактивний йодовмісний гормон щитоподібної залози, котрий разом із тироксином бере участь у регуляції, координації та інтеграції процесів, що відбуваються в організмі. Утворюється 3 молекул тиреоглобіну під час його протеолізу, а також при окисній конденсації моно- та дийодтирозину. Важливою характеристикою даних йодовмісних гормонів є їхня низька видоспецифічність. Виходячи 3 цього організм споживача буде сприймати дані гормони як власні. На нашу думку висока концентрація як трийодтироніну, так і тироксину в секреті молочної залози на 1-4 доби лактації, може пояснюватися потребою стимулювання метаболічних процесів у телят раннього віку, оскільки у них ендокринна система ще $\epsilon$ не зрілою. До подібної думки прийшли й інші дослідники (Osorio et al., 2013; Hammon et al., 2013; Schäff et al., 2014). У цей ж період встановлено низьку концентрацію гормонів у плазмі крові корів. Враховуючи різносторонню фізіологічну дію йодовмісних гормонів, однозначно пояснити встановлені коливання важко. 3 одного боку низький вміст трийодтироніну та тироксину може бути пов'язаний з їхнім виділенням разом 3 молоком, а 3 іншого - 3 формуванням лактаційної домінанти. Після отелення низький рівень тиреоїдних гормонів дозволяє зменшити активність використання енергетичних сполук в тканинах тіла та підвищити їх доступність для молочної залози. Це один із механізмів перерозподілу енергії на користь молокоутворення (Stojić et al., 2001; Pezzi et al., 2003, Simonov, 2013). Однак, зустрічаються також дані (Babitha et al., 2011), які це заперечують, пояснюючи зміни рівня даних гормонів у молозиві виключно добовими ритмами.

Зниження рівня гормонів щитоподібної залози у молоці корів на більш пізніх термінах лактації може бути пов'язано із змінами метаболізму в організмі корів, зниженням потреби телят в екзогенних гормонах та 3 високою долею вірогідності підтверджує гіпотезу, висловлену попередньо. Враховуючи той факт, що дані гормони не $\epsilon$ видоспецифічними, молоко отримане на більш пізніх термінах лактації, буде нести меншу потенційну загрозу здоров'ю людини.

Вірогідне зростання концентрації трийодтироніну та тироксину в плазмі крові корів починаючи з 10-14 доби може свідчити про те, що разом із зростанням продуктивності відбувається підвищення активності гіпофізу та щитоподібної залози. Тиреоїдні гормони діють спільно з глюкокортикоїдами, посилюючи обмінні процеси в організмі корів (Simonov, 2013; Forhead \& Fowden, 2014).

Звертає на себе увагу значно вищий абсолютний вміст тироксину, порівняно 3 трийодтироніном, у плазмі крові корів упродовж цілого досліду. Як свід- 
чать літературні дані (Gubskyi, 2000) від 1/3 до 1/5 загальної кількості тиреоїдних гормонів, що виробляються щитоподібною залозою, надходить у кров відразу у формі трийодтироніну. Решта 2/3-4/5 надходять в кров у формі біологічно малоактивного тироксину, що $є$ фактично прогормоном. Але в периферичних тканинах тироксин за допомогою металоферментів селен-залежною монодейодиназою піддається дейодуванню, конвертується в трийодтиронін.

\section{Висновки}

Отриманий у ході виконання роботи цифровий матеріал вказує на те, що найбільший рівень виділення 3 молоком йодовмісних гормонів щитоподібної залози реєструється на 1-4 добу лактації. Далі концентрація гормонів у молоці вірогідно $(\mathrm{P}<0,001)$ знижується у 2,8-3 рази до 30-40 доби лактації. Висока концентрація йодовмісних гормонів у молозиві дозволяє стимулювати обмінні процеси у телят.

Дослідження концентрації гормонів щитоподібної залози у плазмі крові корів показали поступове зростання від початку лактації до 10-14 і далі до 3040 доби лактації. До 10-14 доби рівень трийодтироніну зріс у 2,2 рази (Р < 0,001), а до 30-40 доби ще на $12,5 \%$. Рівень тироксину на 10-14 добу лактації був вищим, порівняно із іiї початком, на 62,2 \% (P < 0,001), а на 30-40 - на 40,9\%. Основними причинами таких змін $є$ формування лактаційної домінанти, виділення гормонів з секретом молочної залози та стимулювання обмінних процесів впродовж лактації.

Перспектива подальших досліджень полягає у досліджені залежності рівня трийодтироніну та тироксину в секреті молочної залози від продуктивності, породи, віку та годівлі тварин.

\section{References}

Babitha, V., Philomina, P. T. \& Dildeep V. (2011). Effect of extended colostrum feeding on the plasma profile of insulin, thyroid hormones and blood glucose of crossbred pre-ruminant calves. Indian J. Physiol Pharmacol., 55(2), 139-146. https://pubmed.ncbi.nlm. nih.gov/22319894.

Duarte-Salles, T., Fedirko, V., Stepien, M., Trichopoulou, A., Bamia, C., Lagiou, P., Lukanova, A., Trepo, E., Overvad, K., Tjønneland, A., Halkjaer, J., BoutronRuault, M.C., Racine, A., Cadeau, C., Kühn, T., Aleksandrova, K., Trichopoulos, D., Tsiotas, K., Boffetta, P., Palli, D., Pala, V., Tumino, R., Sacerdote, C., Panico, S., Bueno-de-Mesquita, H.B., Dik, V.K., Peeters, P.H., Weiderpass, E., Torhild Gram, I., Hjartåker, A., Ramón Quirós, J., Fonseca-Nunes, A., MolinaMontes, E., Dorronsoro, M., Navarro Sanchez, C., Barricarte, A., Lindkvist, B., Sonestedt, E., Johansson, I., Wennberg, M., Khaw, K.T., Wareham, N., Travis, R.C., Romieu, I., Riboli, E. \& Jenab, M. (2014). Dairy products and risk of hepatocellular carcinoma: the European Prospective Investigation into Cancer and $\mathrm{Nu}-$ trition. Int J Cancer, 135(7), 1662-1672. doi: 10.1002/ijc.28812.
Forhead, A. J., \& Fowden, A. L. (2014). Thyroid hormones in fetal growth and prepartum maturation. J. Endocrinol., 221(3), 87-103. doi: 10.1530/JOE-140025.

Foroutan, A., Guo, A. C., Vazquez-Fresno, R., Lipfert, M., Zhang, L., Zheng, J., Badran, H., Budinski, Z., Mandal, R., AmetajDavid, B. N., \& Wishart, S. (2019). Chemical Composition of Commercial Cow's Milk. J. Agric. Food Chem, 67(17), 4897-4914. doi: 10.1021/acs.jafc.9b00204.

Frezza, V., Fierro, C., Gatti, E., Peschiaroli, A., Lena, A.M., Petruzzelli, M. A., Candi, E., Anemona, L., Mauriello, A., Pelicci, P. G., Melino, G., \& Bernassola, F. (2018). $\Delta$ Np63 promotes IGF1 signalling through IRS1 in squamous cell carcinoma. Aging (Albany NY), 10(12), 4224-4240. doi: 10.18632/aging.101725.

Gubskyi, Ju. I. (2000). Biologichna himija: Pidruchnik [Biological Chemistry: Textbook]. Ukrmedknyga, Kyiv-Ternopil (in Ukrainian).

Hammon, H. M., Steinhoff-Wagner, J., Flor J., Schönhusen U. \& Metges, C. C. (2013). Lactation Biology Symposium: role of colostrum and colostrum components on glucose metabolism in neonatal calves. J. Anim. Sci., 91(2), 685-695. doi: 10.2527/jas.20125758.

Malekinejad, H., \& Rezabakhsh, A. (2015). Hormones in Dairy Foods and Their Impact on Public Health. A Narrative Review Article Iran J. Public Health, 44(6), 742-758. https://www.ncbi.nlm.nih.gov/pmc/articles/ PMC4524299.

Osorio, J. S., Trevisi, E., Ballou, M. A., Bertoni, G., Drackley, J. K., \& Looret J. J. (2013). Effect of the level of maternal energy intake prepartum on immunometabolic markers, polymorphonuclear leukocyte function, and neutrophil gene network expression in neonatal Holstein heifer calves. J. Dairy Sci., 96(6), 3573-3587. doi: 10.3168/jds.2012-5759.

Pezzi, C., Accorsi, P., Vigo, D. Govoni, N., \& Gaiani, R. (2003). 5'-deiodinase activity and circulating thyronines in lactating cows. J. of Dairy Science, 86(1), 152-158. doi: 10.3168/jds.S0022-0302(03)73595-4.

Rieunier, G., Wu, X., Macaulay, V. M., Lee, A. V., Weyer-Czernilofsky, U. \& Bogenrieder, T. (2019). Bad to the Bone: The Role of the Insulin-Like Growth Factor Axis in Osseous Metastasis. Clin Cancer Res., doi: 10.1158/1078-0432.CCR-18-2697.

Rogers, I., Emmett, P., Gunnell, D., Dunger, D., \& Holly J. (2006). Milk as a food for growth? The insulin-like growth factors link. Public Health Nutr., 9(3), 359368. doi: 10.1079/phn2006853.

Schäff, C. T., Rohrbeck, D., Steinhoff-Wagner, J., Kanitz, E., Sauerwein, H., Bruckmaier, R. M., \& Hammon, H. M. (2014). Effects of colostrum versus formula feeding on hepatic glucocorticoid and $\alpha_{1-}$ and $\beta_{2-}$ adrenergic receptors in neonatal calves and their effect on glucose and lipid metabolism. J. Dairy Sci., 97(10), 6344-6357. doi: 10.3168/jds.2014-8359.

Simonov, M. R. (2013). Vmist gormoniv shhytopodibnoi' ta pryshhytopodibnoi' zaloz u plazmi krovi vysokoproduktyvnyh koriv na riznyh fazah laktacii' ta 
periodah utrymannja. Naukovo-tehnichnyj bjuleten' Instytut biologii' tvaryn ta DNDKI vetpreparativ ta kormovyh dobavok, 14(1-2), 59-62 (in Ukrainian).

Stojić, V., Gvozdić, D., Danijela, K., Nikolić-Ana, J., Huszenicza, G., Šamanc, H., \& Ivanov, I. (2001). Serum thyroxine and triiodothyronine concentrations prior to and after delivery in primiparous holstein cows. Acta Veterinaria, 51(1), 3-8.

Tsyupko, V. V. (2010). Composition of cows' butterfat in different terms after calving. Visnyk of Dnipropetrovsk University. Biology. Ecology, 18(2). 119-122. doi: 10.15421/011036 (in Ukrainian). 